\title{
THE IMPROVEMENT OF THE BUSINESS SYSTEM OF THE NORTHERN REGION OF RUSSIA ON THE BASIS OF INNOVATIVE INFRASTRUCTURE DEVELOPMENT
}

\author{
Irina Veniaminovna Takmasheva ${ }^{1}$, Alena Borisovna Zelinskaya ${ }^{1}$, Lyubov Leonidovna \\ Bogomolova $^{1}$
}

${ }^{1}$ Yugra State University, Khanty-Mansiysk, Chekhova Street, 16, The Russian Federation, 628011

\begin{abstract}
The main purpose of the article is to consider the possibility of improvement of the business system on the example of the Northern region on the basis of the innovative infrastructure development. The innovative direction plays an important role in solving the problem of the entrepreneurial sphere improvement. Taking into account the fact that the regional authorities were set the tasks for stimulating the accelerated development of the business sector and the creation of additional innovation infrastructure facilities, the authors of this study put forward the hypothesis that the existing innovation infrastructure in the Khanty-Mansiysk Autonomous Okrug - Yugra is characterized by high performance indicators. However, the hypothesis of the authors was not confirmed in the course of the study. The authors of the study come to the conclusion that the most important directions of the entrepreneurship development should include: support for companies that increase internal costs on research and development; encouraging the implementation of ecological innovations; increasing the number of developed advanced technologies and intellectual property in the region by creating conditions for constant comfortable living of the personnel involved in scientific research and development (researchers, technicians, supporting and other personnel). Statistical, economic and mathematical methods of economic analysis, logical method were used in the study.
\end{abstract}

Keywords: improvement, innovation infrastructure, entrepreneurship.

\section{INTRODUCTION}

The problem of the business sector improvement on the basis of implementation of innovation infrastructure elements becomes more and more relevant every day. New global economic challenges for small and medium enterprises are in the stochasticity of technology development, the growing importance of digital technologies, the turn from standardized production towards the individualization of goods and services, depending on the consumers' tastes.

The business sector is becoming the object of attention of many national and foreign scientists now. Both researchers and government officials do not dispute the fact that the modernization of the economy is possible only with the improvement of the business sector, including on the basis of the innovative infrastructure development. The business sector is being studied from various positions today. For example, many national economists consider entrepreneurship as a special form of economic activity and a driver of economic growth in cities and regions of the country (Melnikov, P.A. and I.I. Pyankov, 2017; Praliev, B.S., 2017).

According to a number of other scientists, social entrepreneurship will play an important role in social protection and adaptation of people who are in need of special protection in the future (Akhmetshina, A.A., 2017; Kosareva, K.I., 2017). Some foreign scientists agree with this position (Roger, M. and S. Osberg, 2007; Seelos, C. and J. Mair, 2005).

Implementation of an effective cluster policy as the main element of the innovation infrastructure development is very important (Ivleva, E.S., L.V. Tserkasevich and N.S. Shashina, 2016). According to other scientists, taking into account the popularity of the conception of the innovative entrepreneurship development in the national economy, the achievement of the innovative development task is possible only at creating the necessary conditions for the effective work of a group of innovative entrepreneurs (Raskina, L.N. and T.P. Telnova, 2016).

According to the authors of this article the studies of the business sector condition conducted by foreign scientists are very significant. Foreign researchers raise a number of relevant questions. In many countries scientists research the factors that determine the level of success of women in business (Kumari Amrita, Chandra Prakash Garg and Saumya Singh, 2018). Close attention abroad is also paid

Submit Date: 09.01.2018, Acceptance Date: 23.02.2018, DOI NO: 10.7456/1080MSE/150

Research Article - This article was checked by Turnitin

Copyright $\mathbb{C}$ The Turkish Online Journal of Design, Art and Communication 
to the development of the family business (Mathew Hughes, Matthias Filser, Rainer Harms, Sascha Kraus and Cheng-Feng Cheng, 2017). Thus, economists analyze the factors affecting the efficiency of family businesses and give appropriate recommendations (Tao Shen, Rutgers, Arturo E. Osorio and Alexander Settles, 2017). Some foreign authors believe that the state should support rural enterprises due to the fact that they are not as competitive as large urban enterprises (Lúcia Pato and Aurora Amélia Castro Teixeira, 2018). Other foreign authors point to the need for the venture capital development and government support for startups (Jonghoon Lee and Taehyun Jung, 2017). Some authors attempt to classify general and innovative business models and come to the conclusion that the willingness of companies to experiment and develop is associated with the innovations implemented at the enterprise (David L. Brannon and Johan Wiklund (2016).

Foreign researchers as well as national scientists are engaged in the study of the problems of effective construction of the social and economic space of territories, including on the basis of the entrepreneurship development (Braczyk, H.-J. and M. Heidenreich, 1998; Foddi, M. and S. Usai, 2013). These problems were considered in writings of R. Camagni, R. Capello, S. Lenzi (Camagni, $R$. and R. Capello, 2013; Capello, R. and C. Lenzi, 2013; Capello, R., 2013).

\section{MATERIALS AND METHODS}

The authors of this article selected as the object of the study the innovative infrastructure of the business system of the Northern region - Khanty-Mansiysk Autonomous Okrug - Yugra. The aim of the study is to evaluate the effectiveness of the innovation infrastructure functioning of the business sector of the Northern region on the basis of clear criteria and taking into account the state of the business environment parameters.

Objectives of the study: 1) analysis of the innovation infrastructure facilities of the business sector, operating in the territory of Yugra; 2) the choice and justification of absolute and relative indicators characterizing the effectiveness of the innovation infrastructure of the entrepreneurial sphere of the Northern region; 3) analysis and economic assessment of changes selected for the study of absolute and relative indicators in the Khanty-Mansiysk Autonomous Okrug for the period from 2012 to 2016; 4) identification of unfavorable trends in the innovation infrastructure of the business sector and formulation of proposals on the directions of the innovative business environment development of Yugra.

The main methods of the presented study were statistical methods, on the basis of which the following stages were implemented: stage 1 - the collection of primary statistical information; stage 2 - the summary and distribution of primary statistical data using the method of statistical groupings; stage 3 - the development of the statistical table layout; stage 4 - the analysis of statistical information using the method of generalizing indicators.

Establishment of cause-effect relationships and dependencies, analysis of the patterns of processes development occurring in the innovative business environment of the Northern region, was carried out by the authors using the logical method. In addition, the study used research techniques such as analysis, synthesis, induction, deduction, modeling, abstraction, comparison and analogy. The authors of this study put forward the hypothesis that the existing innovative infrastructure of the business sector in the Northern region is characterized by high performance indicators.

\section{RESULTS}

Let us turn to the results of the analysis of the indicators of innovative development of the Northern region. According to the authors of the study, both absolute and relative indicators are important for assessing the efficiency of the innovation infrastructure of the business sector (Table 1). The authors evaluated the changes in these indicators for the period from 2012 to 2016.

Table 1

Dynamics of absolute and relative performance indicators of innovative business infrastructure on the territory of Yugra

\begin{tabular}{|l|l|l|l|l|l|l|}
\hline № & Name of indicator & 2012 & 2013 & 2014 & 2015 & 2016 \\
\hline 1 & \multicolumn{6}{|c|}{ Absolute indicators } \\
\hline
\end{tabular}

Submit Date: 09.01.2018, Acceptance Date: 23.02.2018, DOI NO: 10.7456/1080MSE/150

Research Article - This article was checked by Turnitin

Copyright $\mathbb{C}$ The Turkish Online Journal of Design, Art and Communication 


\begin{tabular}{|c|c|c|c|c|c|c|}
\hline 1.1 . & $\begin{array}{l}\text { number of personnel engaged } \\
\text { in research and development } \\
\text { (people) }\end{array}$ & 1683 & 1665 & 2044 & 1978 & 1831 \\
\hline 1.2 . & $\begin{array}{l}\text { volume of innovative goods, } \\
\text { works, services (millions of } \\
\text { rubles) }\end{array}$ & $\begin{array}{c}2876513 \\
66\end{array}$ & $\begin{array}{c}3085838 \\
60\end{array}$ & $\begin{array}{c}2993431 \\
, 00\end{array}$ & 2952087,48 & $\begin{array}{c}2989128 \\
38\end{array}$ \\
\hline 1.3 . & $\begin{array}{l}\text { internal costs for research and } \\
\text { development (millions of } \\
\text { rubles) }\end{array}$ & 3081,6 & 2714,3 & 2720,3 & 2805,9 & 2800,4 \\
\hline 1.4. & $\begin{array}{l}\text { costs for technological } \\
\text { innovation of organizations } \\
\text { on the types of innovative } \\
\text { activity (million rubles) }\end{array}$ & 21465,50 & 51164,60 & $\begin{array}{c}54305,9 \\
0\end{array}$ & 57166,60 & 61874,61 \\
\hline 1.5 . & $\begin{array}{l}\text { special costs associated with } \\
\text { environmental innovation } \\
\text { (millions of rubles) }\end{array}$ & 8060,93 & 7999,92 & 2852,27 & 4884,74 & 4478,34 \\
\hline 1.6. & $\begin{array}{l}\text { developed advanced } \\
\text { production technologies } \\
\text { (units) }\end{array}$ & 2,00 & 3,00 & 1,00 & 0,00 & 0,00 \\
\hline 1.7 . & $\begin{array}{l}\text { used advanced production } \\
\text { technology (units) }\end{array}$ & 1839,00 & 2049,00 & 1328,00 & 1309,00 & 1969,00 \\
\hline 1.8. & $\begin{array}{l}\text { information on the use of } \\
\text { intellectual property objects } \\
\text { (units) }\end{array}$ & 0,00 & 0,00 & 0,00 & 0,00 & 0,00 \\
\hline 2 & \multicolumn{6}{|c|}{ Relative indicators } \\
\hline 2.1 . & $\begin{array}{l}\text { share of organizations } \\
\text { implementing technical } \\
\text { innovations in the total } \\
\text { number of surveyed } \\
\text { organizations }(\%)\end{array}$ & 5,60 & 5,60 & 3,80 & 3,60 & 4,50 \\
\hline 2.2 & $\begin{array}{l}\text { share of innovative goods, } \\
\text { works, services in the total } \\
\text { volume of shipped goods, } \\
\text { performed works, services } \\
(\%)\end{array}$ & 0,33 & 0,20 & 0,30 & 0,30 & 0,40 \\
\hline 2.3 & $\begin{array}{l}\mathrm{sh} \text { a r e of cost s o n } \\
\text { technological innovations in } \\
\text { the total volume of shipped } \\
\text { goods, works and services } \\
(\%)\end{array}$ & 0,75 & 1,66 & 1,80 & 1,94 & 2,07 \\
\hline 2.4 . & $\begin{array}{l}\text { share of organizations } \\
\text { engaged in marketing } \\
\text { innovations in the total } \\
\text { number of surveyed } \\
\text { organizations }(\%)\end{array}$ & 0,50 & 1,00 & 0,60 & 0,60 & 0,40 \\
\hline
\end{tabular}




\begin{tabular}{|c|c|c|c|c|c|c|}
\hline 2.5 & $\begin{array}{l}\text { share of organizations } \\
\text { implementing organizational } \\
\text { innovations in the total } \\
\text { number of surveyed } \\
\text { organizations }(\%)\end{array}$ & 1,60 & 2,10 & 2,40 & 1,90 & 2,50 \\
\hline 2.6 . & $\begin{array}{l}\text { share of organizations } \\
\text { implementing environmental } \\
\text { innovations in the total } \\
\text { number of surveyed } \\
\text { organizations }(\%)\end{array}$ & 4,20 & 2,19 & 0,70 & 0,80 & 1,10 \\
\hline 2.7 & $\begin{array}{l}\text { share of small enterprises } \\
\text { engaged in technological } \\
\text { innovations in the total } \\
\text { number of surveyed small } \\
\text { enterprises }(\%)\end{array}$ & 3,60 & 3,38 & 1,38 & 1,84 & 3,53 \\
\hline 2.8 & $\begin{array}{l}\text { share of innovative goods, } \\
\text { works, services in the total } \\
\text { volume of shipped goods, } \\
\text { performed works, services of } \\
\text { small enterprises }(\%)\end{array}$ & 0,00 & 0,00 & 0,11 & 0,02 & 0,79 \\
\hline
\end{tabular}

Source: compiled by the authors on the basis of official data of the Federal State Statistics Service of Russia

\section{CONSIDERATION}

The number of personnel engaged in research and development has increased in the region during the period under review by $8.79 \%$ from 1,683 to 1,831 people, which is a very good trend. The analysis of the categories of personnel revealed that researchers make up $76.68 \%$ of the total number of personnel engaged in research and development, support staff is $10.10 \%$, technicians $-8.52 \%$, other personnel $-4.70 \%$.

The volume of costs for technological innovations of organizations on various types of innovative activity increases annually at a significant pace. This indicator has risen for five years by 188.25\% (from 21465.50 million rubles in 2012 to 61874.61 million rubles in 2016). The costs of technological innovation reflect the organization's cash costs for innovation activities in the region. The main purpose of technological innovation is to improve or create a new type of product or service. Taking this into account, it is very interesting that the volume of innovative goods, works and services has increased slightly for five years only by $3.91 \%$.

The revealed trends allow drawing a conclusion about the lack of efficiency of technological innovations at the enterprises of the Northern region. There is a significant discrepancy between the costs of technological innovation of organizations and the volume of produced goods, works and services on the market as a result of such innovations. Internal costs of research and development tend to decrease. The internal costs of research and development of organizations has decreased by $9.13 \%$ for five years. Special costs related to environmental innovations also decreased significantly from 8060.93 million rubles in 2012 to 2852.27 million rubles in 2014 , and then to 4.478 .34 million rubles in 2016 - in total for five years by $44.44 \%$. The reduction of internal research costs and special costs associated with environmental innovation may indicate an unstable financial condition of organizations and an unfavorable business environment.

The number of advanced production technologies developed over the past two years has remained at zero level. The largest number of advanced production technologies was developed in 2013 (3 units). Despite this, the use of advanced production technologies at the enterprises of the region remains at a high level: 1839 technologies were used in 2012, it was 1969 in 2016 (growth by $7.07 \%$ for five years). There is no information on the use of intellectual property during the period under review. 


\section{CONCLUSIONS}

As shown by the conducted research, currently a significant number of innovation infrastructure facilities have been created on the territory of the Khanty-Mansiysk Autonomous Okrug - Yugra. Despite this, the analysis of absolute and relative indicators characterizing the efficiency of the innovative infrastructure of the business sector of the Northern region revealed very unfavorable trends. Thus, the internal costs of organizations for research and development from 2012 to 2016 tend to decrease. The costs of environmental innovation are characterized by a tremendous decrease of $44.44 \%$ for five years. The number of developed advanced production technologies in 2012 was 2 units, in 2013 - 3 units, from 2014 to 2016 no advanced production technology was created. After analyzing these facts, it can be concluded that the Khanty-Mansiysk Autonomous Okrug - Yugra is not an advanced region in the development of production technologies and intellectual property, that is, the appropriate conditions for this on the territory of Yugra have not been created yet. Besides, the Northern region is a recipient region of advanced production technologies developed in other regions of Russia and countries.

Based on these conclusions, it should be recognized that the activities of regional authorities and organizations of innovation infrastructure aimed at the innovative development of the region is ineffective due to the fact that the activities set out in the strategic documents are implemented in fragmentary manner. Thus, the hypothesis of the authors of this study that the innovative infrastructure of the business sector of Yugra characterized by high performance indicators was not confirmed.

On the basis of the identified trends in the innovative business environment, according to the authors of this study, the most important directions of the business sector development in the nearest future should be: support of enterprises that increase the internal costs of the organization for research and development; encouraging the environmental innovation, creating conditions for the environmental production, rational and safe operation of the natural resource potential of the region; increasing the number of developed advanced technologies and intellectual property in the region by creating conditions for permanent comfortable living of staff engaged in research.

\section{ACKNOWLEDGEMENTS}

The publication was prepared in the course of scientific research at the expenses of the grant for the development of scientific ideas for research teams under the guidance of a young scientist Candidate of Sciences in the priority areas of research of Yugra State University (project №13-01-20/12 from 09.01.2018).

\section{Conflict of interest}

The authors confirm that the presented data do not contain a conflict of interest.

\section{REFERENCES}

Melnikov, P.A., Pyankov, I.I. Entrepreneurship as a special form of economic activity / P.A. Melnikov, I.I. Pyankov // New science: from idea to result. - 2017. - Vol. 1. - № 2. - P. 128-131.

Praliev, B.S. Development of entrepreneurship as a driver of growth of the single-industry towns economy / B.S. Praliev // Beneficiary. - 2017. No. 5. - P. 24-26.

Akhmetshina, A.A. Social entrepreneurship as a factor of effective social adaptation of people with disabilities: functions and role in society / A.A. Akhmetshina // Bulletin of Economics, Law and Sociology. 2017. No. 2. P. 135-138.

Kosareva, K.I. Social entrepreneurship as a vector of employment of unprotected segments of the population / K.I. Kosareva // Scientific notes of the Tambov branch RUYS. 2017. No. 7. P. 196-199. Ivleva, E.S., L.V. Tserkasevich and N.S. Shashina (2016). Cluster approach as a strategic direction of entrepreneurship development in the innovative economy. Economics and management, 7, 28-32.

Raskina, L.N. and T.P. Telnova (2016). Innovative entrepreneurship in Russia: state and prospects. Trade, business and law, 3, 44-56.

Submit Date: 09.01.2018, Acceptance Date: 23.02.2018, DOI NO: 10.7456/1080MSE/150

Research Article - This article was checked by Turnitin

Copyright (C) The Turkish Online Journal of Design, Art and Communication 
Roger, M. and S. Osberg (2007). Social Entrepreneurship: The Case for Definition. Stanford Social Innovation Review, 2007, pp. 1-39.

Seelos, C. and J. Mair (2005). Social entrepreneurship: Creating new business models to serve the poor. In: Business Horizons, 2005, no. 48, pp. 241-246.

Kumari Amrita, Chandra Prakash Garg and Saumya Singh (2018). Modelling the critical success factors of women entrepreneurship using Fuzzy AHP framework. Journal of Entrepreneurship in Emerging Economies; doi:10.1108/JEEE-03-2017-0017.

Mathew Hughes, Matthias Filser, Rainer Harms, Sascha Kraus and Cheng-Feng Cheng (2017). Family Firm Configurations for High Performance: The Role of Entrepreneurship and Ambidexterity. British Journal of Management 12/2017; (in press)(4); doi:10.1111/1467-8551.12263

Tao Shen, Rutgers, Arturo E. Osorio and Alexander Settles (2017). Does Family Support Matter ? The Influence of Support Factors an Entrepreneurial Attitudes and Intentions of College Students. Academy of Entrepreneurship Journal, volume 23, 1, 24-43.

Lúcia Pato and Aurora Amélia Castro Teixeira (2018). Rural entrepreneurship: the tale of a rare event. Journal of Place Management and Development; doi:10.1108/JPMD-08-2017-0085.

Jonghoon Lee and Taehyun Jung (2017). Policy-driven expansion of venture capital industry: an empirical examination of contexts, factors, and effects behind the recent surge of korean venture capital industry. Academy of Entrepreneurship Journal, volume 23, 1, 11-23.

David L. Brannon and Johan Wiklund (2016). An analysis of business models: firm characteristics, innovation and performance. Academy of Entrepreneurship Journal, volume 22, 1, 1-20.

Braczyk, H.-J. and M. Heidenreich (1998). Regional governance structures in a globalised world. In Braczyk H.-J., Cooke P., Heidenreich M. Regional Innovation Systems. London: UCL Press.

Foddi, M. and S. Usai (2013). Regional Knowledge Performance in Europe. Growth and Change, 44(2), 258-286.

Camagni, R. and R. Capello (2013). Regional Innovation Patterns and the EU Regional Policy Reform: Towards Smart Innovation Policies. Growth and Change, 44(2), 355-389.

Capello, R. and C. Lenzi (2013). Territorial patterns of innovation: a Taxonomy of innovative regions in Europe. Ann Reg Sci. 51, 119-154.

Capello, R. (2013). Knowledge, Innovation, and Regional Performance: Toward Smart Innovation Policies Introductory Remarks to the Special Issue. Growth and Change, 44(2), 185-194.

The Regions of Russia. Socio-economic indicators. 2017: Statistical pocketbook, 2017. Moscow: Rosstat, pp. 1402. 